УДК 636.2:619:616.3:619:616.995.1:619:615

(C) 2012

Кручиненко О. В., кандидат ветеринарних наук

Полтавська державна аграрна академія

Прус М. П., доктор ветеринарних наук, професор

Національний університет біоресурсів та природокористування України

Шабалін О. М., головний лікар ветеринарної медицини

ТОВ «Джерело» Полтавського району Полтавської області

\title{
ТЕРАПЕВТИЧНА Й ЕКОНОМІЧНА ЕФЕКТИВНІСТЬ АНТИ- ГЕЛЬМІНТИКІВ ЗА ШЛУНКОВО-КИШКОВИХ ГЕЛЬМІНТОЗІВ КОРІВ
}

\section{Рецензент - доктор ветеринарних наук В. О. Свстаф'єва}

\begin{abstract}
Наведені результати досліджень стосовно терапевтичної та економічної ефективності альбендазолу ультра $10 \%$, комбітрему й рафензолу. Встановлено, щзо при одночасному паразитуванні парамфістом, дикрочелій, фасиіол й стронгілят органів травлення комбітрем та рафензол проявляють $100 \%$ екстенс- та інтенсефективність, а альбендазол ультра $10 \%$, відповідно, $90 \%$ й $75 \%$. Дегельмінтизачія корів забезпечує зростання молочної продуктивності у тварин: за лікування альбендазолом ультра $10 \%$ на 14,3\%, комбітремомна 17,6\% і рафензолом - на 20,6\%, а від реалізачії молока, надоєного від корів трьох дослідних груп, додатково отримано 1308 гривень.
\end{abstract}

Ключові слова: корови, гельмінти, антигельмінтики, ефективність.

Постановка проблеми. Останні повідомлення науковців і практичних фахівців свідчать про складну епізоотичну ситуацію стосовно гельмінтозів шлунково-кишкового каналу корів. Дані літературних джерел доводять, що у великої рогатої худоби найчастіше реєструють фасціольоз, дикроцеліоз, парамфістомоз, стронгілятози органів травлення [4]. За змішаної інвазії у тварин виявляють більш тяжкий перебіг, аніж за моноінвазії. До того ж знижуються добові надої молока від кожної корови на 10-15\%, яловість їх сягає 7-9\%, а середньодобовий приріст молодняка знижується на 9,4-14 \% [1].

Аналіз основних досліджень і публікацій, у яких започатковано розв'язання проблеми. За останні 10-15 років з'явилася значна кількість робіт із вивчення гельмінтозів великої рогатої худоби. У своїх дослідженнях автори проводили визначення терапевтичної ефективності препаратів вітчизняного та закордонного виробництва. Використання комплексних схем антигельмінтиків (роленолу, вермітану й альбендазолу) та імуностимуляторів забезпечувало зростання добово- го надою молока від одної корови на $0,77-0,98$ кг за окупності додаткових витрат 12,20-21,13 грн [2]. Найвищий лікувальний ефект за фасціольозно-парамфістомозної інвазії великої рогатої худоби був досягнутий від застосування комбітрему і бітіонолу [5]. В експериментальних випробуваннях екстенс- та інтенсефективність комбітрему становила $100 \%$, а середньодобовий надій молока на корову в дослідній групі перевищував показники контрольної групи на 2,8 кг, а через два місяці - на 3,1 кг [3]. При дегельмінтизації корів фенбендазолом у першій декаді грудня, за мікстінвазії, вдавалося отримати від кожної корови додатково по 62 кг молока протягом п'яти місяців спостереження [6].

Мета і завдання досліджень. Враховуючи вищенаведене, метою наших досліджень було вивчити епізоотичну ситуацію 3 гельмінтозів шлунково-кишкового каналу великої рогатої худоби у ТОВ «Джерело» МТФ с. Івашки Полтавського району за показниками екстенсивності (EI) та інтенсивності інвазії (II), провести порівняння терапевтичної й економічної ефективності альбендазолу ультра $10 \%$, комбітрему і рафензолу.

Матеріали і методи досліджень. Екстенсивність та інтенсивність інвазії визначали наприкінці листопада 2011 року за методом I. С. Дахна та визначення ступеня ураженості тварин гельмінтами (яєць в 1 г фекалій за В. Н. Трачем). Випробування препаратів проводили на трьох дослідних та одній контрольній групах тварин, по 10 голів у кожній.

Економічну ефективність визначали за показником молочної продуктивності тварин дослідних і контрольної груп до дегельмінтизації та протягом двох місяців після застосування препаратів. Із цією метою підібрали корів-аналогів по 10 голів із дослідних і контрольної груп з урахуванням їхнього віку, маси тіла, фізіологічного стану та періоду отелення. 
Першій групі задавали альбендазол ультра $10 \%$ у формі порошку (виробництва «АгpoZooBeт») перорально разом із комбікормом у дозі 1 г/10 кг маси тіла. Другій - комбітрем порошок (виробництва НВФ «Бровафарма») у дозі 1 г/10 кг маси тіла перорально одноразово з комбікормом. Третій - рафензол емульсію (виробництва НВФ «Бровафарма») - перорально з 200 мл теплої води у дозі 1 мл/50 кг маси тіла. Четверта слугувала контролем і препаратів не отримувала.

Результати досліджень. За копроовоскопічного дослідження корів до дегельмінтизації у тварин першої та другої дослідних груп виявляли яйця фасціол, дикроцелій та стронгілят органів травлення; у тварин третьої дослідної та контрольної групи - яйця парамфістом, дикроцелій, фасціол та стронгілят органів травлення. Як видно 3 даних таблиці 1, до введення препаратів екстенсивність інвазії у трьох дослідних та контрольній групах становила $100 \%$. Показники інтенсивності інвазії були різними. Так, найвища інтенсивність фасціольозної інвазії фасціолами була зареєстрована у тварин другої дослідної групи, дикроцеліями - першої, стронгілятами органів травлення - другої, а парамфістомами у третьої. Через 30 діб після дегельмінтизації у тварин другої й третьої дослідних груп, за даними копроовоскопії, яєць гельмінтів не виявили. У тварин, дегельмінтизованих альбендазолом ультра $10 \%$, виявляли яйця дикроцелій, а екс- тенс- та інтенсефективність препарату становила, відповідно, 90,0 \% і 75,0 \%.

У контрольної групи ЕI залишалася незмінною, відповідно, $100 \%$. Інтенсивність інвазії на $30-$ добу зростала й становила: парамфістомами $6,5 \pm 0,8$, дикроцеліями - 2,0 0,3 фасціолами $3,9 \pm 0,1$ і стронгілятами органів травлення $8,6 \pm 0,7$ екз. яєць в 1 г фекалій. Враховуючи високу ураженість тварин контрольної групи, через два місяці від початку досліду їх також було дегельмінтизовано.

До дегельмінтизації середньодобовий надій молока на корову в першій, другій, третій дослідній i контрольній групах становив, відповідно, $12,5 \pm 0,8$, $12,6 \pm 1,7,12,8 \pm 1,5$ і $12,7 \pm 1,4$ кг (табл. 2). Через місяць після застосування альбендазолу ультра $10 \%$, комбітрему й рафензолу середньодобовий надій молока на корову в дослідних групах перевищував показники контрольної групи тварин, відповідно, на 0,9, 1,3 і 1,8 кг. Наприкінці другого місяця спостережень у першій дослідній групі корів (порівняно 3 контрольною) продуктивність була вищою на $14,3 \%$, у другій - на $17,6 \%$ а третій - на 20,6 \%. За два місяці лактації продуктивність корів, оброблених альбендазолом ультpa $10 \%$, була вищою на 81 кг, комбітремом на 108 кг і рафензолом - на 138 кг порівняно з коровами контрольної групи. На період проведення досліджень реалізаційна ціна 1 ц молока становила 400 гривень.

\section{1. Терапевтична ефективність препаратів за гельмінтозів илунково-кишкового тракту корів}

\begin{tabular}{|c|c|c|c|c|c|c|c|c|}
\hline \multirow{2}{*}{$\begin{array}{l}\text { Групи } \\
\text { тварин }\end{array}$} & \multicolumn{3}{|c|}{ До дегельмінтизації } & \multicolumn{3}{|c|}{$\begin{array}{c}\text { Через } 30 \text { діб } \\
\text { після дегельмінтизації }\end{array}$} & \multirow{2}{*}{$\begin{array}{c}\mathrm{EE}, \\
\%\end{array}$} & \multirow{2}{*}{$\begin{array}{l}\mathrm{IE}, \\
\%\end{array}$} \\
\hline & $\begin{array}{c}\text { гельмін- } \\
\text { този }\end{array}$ & $\begin{array}{c}\text { II, екз. в } 1 \text { г } \\
\text { фекалій }\end{array}$ & EI, \% & $\begin{array}{l}\text { гельмін- } \\
\text { този }\end{array}$ & $\begin{array}{c}\text { II, екз. в } 1 \text { г } \\
\text { фекалій }\end{array}$ & EI, \% & & \\
\hline \multirow{3}{*}{$\begin{array}{l}\text { Перша } \\
\text { (10 гол.) }\end{array}$} & $\Phi$ & $4,5 \pm 0,41$ & \multirow{3}{*}{100} & $\Phi$ & - & \multirow{3}{*}{10} & \multirow{3}{*}{90} & \multirow{3}{*}{75} \\
\hline & Д & $4,4 \pm 0,65$ & & Д & $1,1 \pm 0,0$ & & & \\
\hline & Стр. & $9,4 \pm 0,1$ & & Стр. & - & & & \\
\hline \multirow{3}{*}{$\begin{array}{c}\text { Друга } \\
\text { (10 гол.) }\end{array}$} & $\Phi$ & $4,6 \pm 0,9$ & \multirow{3}{*}{100} & $\Phi$ & - & \multirow{3}{*}{ - } & \multirow{3}{*}{100} & \multirow{3}{*}{100} \\
\hline & Д & $3,9 \pm 0,71$ & & Д & - & & & \\
\hline & Стр. & $10,4 \pm 1,13$ & & Стр. & - & & & \\
\hline \multirow{4}{*}{$\begin{array}{c}\text { Третя } \\
\text { (10 гол.) }\end{array}$} & $\Pi$ & $6,8 \pm 0,9$ & \multirow{4}{*}{100} & $\Pi$ & - & \multirow{4}{*}{ - } & \multirow{4}{*}{100} & \multirow{4}{*}{100} \\
\hline & $\Phi$ & $2,4 \pm 0,42$ & & $\Phi$ & - & & & \\
\hline & Д & $1,5 \pm 0,24$ & & Д & - & & & \\
\hline & Стр. & $8,6 \pm 1,1$ & & Стр. & - & & & \\
\hline \multirow{4}{*}{$\begin{array}{c}\text { Контрольна } \\
\text { (10 гол.) }\end{array}$} & $\Pi$ & $5,3 \pm 0,8$ & \multirow{4}{*}{100} & $\Pi$ & $6,5 \pm 0,8$ & \multirow{4}{*}{100} & \multirow{4}{*}{ - } & \multirow{4}{*}{ - } \\
\hline & $\Phi$ & $3,3 \pm 1,1$ & & $\Phi$ & $3,9 \pm 0,1$ & & & \\
\hline & Д & $1,2 \pm 0,11$ & & Д & $2,0 \pm 0,3$ & & & \\
\hline & Стр. & $7,9 \pm 0,91$ & & Стр. & $8,6 \pm 0,7$ & & & \\
\hline
\end{tabular}

Примітка: $\Phi$ - фасціоли, Д - дикроцелії, П - парамфістоми, Стр. - стронгілят органів травлення, ЕI - екстенсивність інвазії, II - інтенсивність інвазії, ЕE - екстенсефективність, IE - інтенсефективність 
ВЕТЕРИНАРНА МЕДИЦИНА

\section{2. Показники молочної продуктивності корів до й після дегельмінтизацї̈ корів} альбендазолом ультра 10 \%, комбітремом та рафензолом

\begin{tabular}{|c|c|c|c|c|}
\hline \multirow{3}{*}{ Групи тварин } & \multirow{3}{*}{$\begin{array}{c}\text { Кількість } \\
\text { тварин у групі }\end{array}$} & \multicolumn{3}{|c|}{ Середньодобовий надій молока на одну корову, кг } \\
\hline & & \multirow{2}{*}{ до дегельмінтизації } & \multicolumn{2}{|c|}{ після дегельмінтизації } \\
\hline & & & на 30-ту добу & на 60-ту добу \\
\hline Перша & 10 & $12,5 \pm 0,8$ & $12,8 \pm 1,4$ & $12,6 \pm 1,5$ \\
\hline Друга & 10 & $12,6 \pm 1,7$ & $13,2 \pm 1,5$ & $13,1 \pm 0,9$ \\
\hline Третя & 10 & $12,8 \pm 1,5$ & $13,7 \pm 1,2$ & $13,6 \pm 1,5$ \\
\hline Контрольна & 10 & $12,7 \pm 1,4$ & $11,9 \pm 1,3$ & $10,8 \pm 1,2$ \\
\hline
\end{tabular}

Таким чином, від реалізації молока, надоєного від корів трьох дослідних груп, додатково отримано 1308 гривень. При відрахуванні матеріальних затрат (вартість альбендазолу ультра $10 \%-$ 34,5 грн, комбітрему - 95 грн та рафензолу 190,2 грн, використаних для дегельмінтизації 30 корів) сума чистого прибутку становила: в першій дослідній групі - 289,5 грн, в другій 337 грн, а в третій - 361,8 гривень. Безсумнівним $\epsilon$ той факт, що продуктивність у дегельмінтизованих тварин продовжувала зростати й надалі, в порівнянні з хворими коровами.

\section{БІБЛІОГРАФІЯ}

1. Абдулмагомедов С. Ш. Эффективность некоторых антигельминтиков при смешанных трематодозах крупного рогатого скота / С. Ш. Абдулмагомедов, А. А. Рашидов, А. Д. Алиев [и др.] // Российский паразитологический журнал, 2009. № 3. - С. 90-92.

2. Дахно I. С. Епізоотологія, патогенез, етіотропна та імунокоригуюча терапія при фасціольозі і дикроцеліозі жуйних тварин: автореф. дис. ... доктора вет. наук: спец. 03.00.18 / I. С. Дахно. X., 2001. - $36 \mathrm{c}$.

3. Дахно I. C. Терапевтична та економічна ефективність комбітрему на ранній стадії фасціольозної інвазії корів / І. С. Дахно, Г. П. Дахно, О. В. Кручиненко [та ін.] // Ветеринарна медицина України. - 2004. - №8. - С. 17-19.

4. Дахно I. С. Ефективність деяких антигельмін-

\section{Висновки:}

1. За одночасного паразитування гельмінтів шлунково-кишкового каналу у великої рогатої худоби комбітрем і рафензол проявляють $100 \%$ екстенс- та інтенсефективність, а альбендазол ультра $10 \%$, відповідно, $90 \%$ й $75 \%$.

2. Дегельмінтизація корів антигельмінтиками забезпечує підвищення їх молочної продуктивності: за лікування альбендазолом ультра $10 \%$ на $14,3 \%$, комбітремом - на $17,6 \%$ і рафензолом - на 20,6 \% (за 2 місяці, період спостереження).

тиків при змішаних паразитозах великої рогатої худоби / І. С. Дахно, О. С. Клименко // Проблеми зооінженерії та ветеринарної медицини: $3 б$ наук. праць ХДЗВА. - Х., 2006. - Вип. 13 (38). C. 289-294.

5. Мазанний О. В. Фасціольозно-парамфістоматозна інвазія великої рогатої худоби (особливості епізоотології, діагностика та заходи боротьби): автореф. дис. ... канд. вет. наук: спец. 16.00.11 / О. В. Мазанний - К., 2006. - 20 с.

6. Садов К. М. Ассоциативные паразитарные болезни крупного рогатого скота и разработка рациональной системы бороьбы с ними в условиях Среднего Поволжья: автореф. дис. ... доктора вет. наук: спец. 03.00.19 и 16.00.03 / К. М. Садов. - Иваново, 2008. -44 с. 